\title{
THE APLICATION OF DIGITAL STORYTELLING IN TEACHING SPEAKING
}

\author{
Ircham Asrori D \\ English Education Department \\ Panca Sakti University Bekasi, Jawa Barat, Indonesia \\ himanapfrigant@gmail.com
}

\begin{abstract}
The first aim of this study was to explore the application of digital storytelling in teaching speaking at the students of state senior high school No 1 Pelepat Kabupaten Bungo. Second, it aims to explore the benefits of digital storytelling in contributing to speaking class. Third, it aims to explore the participants' perception. This study used qualitative method. The data collection technique used was observation, interview, and audiovisual material. The participants were an English teacher and six of twenty-four students of eleventh grade. The sampling technique used was purposive sampling. The data was analyzed qualitatively by using triangulation. The first finding was digital storytelling use in teaching speaking as in the following procedures: writing the story, recording the story, collecting related pictures, combining (recording and relevant images), and the last step was presenting and evaluating. The second findings was the application of digital storytelling had some benefits such as it contributed to practice and improve students' speaking skill, the students be familiar with the pronunciations, self-confidence, and evaluated or assessed students' improvement in speaking skill. The last finding of this study showed that the digital storytelling use in teaching speaking provided participants to have positive and negative perception; for example, high motivation in learning, easy, interesting, and enjoyable media, while for negative perceptions were difficulties in editing, limited time, and lack of related images.
\end{abstract}

Keywords: application; digital storytelling; teaching speaking.

\section{INTRODUCTION}

English that people use it as an official language in some countries is the most spoken languages worldwide. Historically, English has changed into an international language after second world war and over a million people speak into it as their first, second or third language across the world. (Ketabdar, Yazdani, and Yarahmadi, 2014).

English already become a universal language that everyone can learn and use. It is the chosen language for international communication. In addition, English is the language of globalization such as in business, politics, and diplomacy. Moreover, the language of science, computer, and internet mostly uses English. As many things involving English, people should learn and use English in order to have communication internationally and globally.

In Indonesia, English is taught as one of foreign language subjects in school curriculum. By the end of the English subject, all students are expected to master four language skills (listening, speaking, reading, and writing). The students are expected to be able to communicate in oral and written form. In oral form, they are expected to be able to speak English fluently and accurately in expressing their ideas.

However, in actual fact, the most students in Indonesia cannot use English to communicate his/her thought, idea, opinion, feeling, etc. which it is contrary to those above-expectations. The students have learned English for six years (3 years at junior and 3 years at senior high school), but their ability especially in speaking skill are still not as expected nevertheless. The students cannot speak English until this present because of less vocabulary and incorrect or poor grammar. Besides, the main problems for students to speak English are because they 
have also low motivation and lack of confidence.

The above-mentioned problems also ever happened in one school in the area of Kabupaten Bungo, State Senior High School No 1 Pelepat. In the preliminary study, the writer has interviewed one of English teachers at the school because students in her class ever had problems in learning English, especially speaking. The problem were the students did not seem so keen to use English as a communication tool in the classroom. They were afraid to speak English because they had a bit of vocabulary and had problems with pronunciation. In addition, the teacher also has stated that the students rarely tried to use and speak in English. When the students worked in groups, they only communicated by using their mother tongues. The students did not know how their thought, idea, opinion, experience, etc. were expressed orally in English. Besides, the teacher has informed that the students ever had problems related to telling stories in English language, especially in English speaking skill. The students looked like so embarrassed which they did not have confidence. They also could not speak English to express their idea or experience. Furthermore, when they were conducting presentations or telling stories in front of the class, the students just looked at the slide and read it.

To engage the students to actively participate in English speaking skill, the English teacher has already provided a solution with paying attention to technology in which she uses it in the teaching and learning process. It is in line with statement, "Educational institutions including schools and higher education institutions should pay more attention to digital learning of materials in classes and consider the focal role of technology in general and DST in particular. The educational institutions should direct their attention to the educational philosophy which is learner-centered; that is, the suitable methodology and practices should be adopted based on the interests and needs analysis of the learners at every level of education." (Tahriri, Tous \& Far, 2015, p. 152). According to Franscy and Fatimah (2019) in creating an effective educational process, teacher involvement from the design of educational innovations to implementation and evaluation plays a very large role for the success of better educational innovations.

In 21 st century, technology has become something which it is very important in life. Most people already communicate opinions, ideas, thoughts, and their expressions through technologies; for example, computer/laptop, internet, power point, e-mail, smartphone, video, messaging, and other media. It is not only a useful tool to build social interaction among people anywhere in the world but also it can be used in educational context as a medium for teaching and learning. Related to the problems in speaking skill, there were several technologies already surveyed by the English teacher. One of them is digital storytelling which she applies it as a learning media.

There have been some definitions about digital storytelling in related literature. As Petruco said, "Digital Storytelling is not a totally new concept, but it is only a new genre or new way of transmitting the stories." (2014, p. 114). Furthermore, Widodo defines, "digital storytelling is a genre that it combines the use of technology, and telling a story in which a particular technology tool mediates the telling of a story." (2014, p. 3).

There are some advantages of digital storytelling. According to Kim, "Digital storytelling has been widely used to help learners communicate their own stories effectively since it can be a learner-centered activity when the topic is related to their daily life and personal subject matter." (2014, p. 22). It is an appropriate media to support the learner-centered. In addition, Sepp and Rao (2015) have said, "Digital storytelling can help engage English language learners and motivate them to learn. It invites students to improve their writing skill and speaking skills in a creative way." Boase (2016) has said that there are varieties of skill can be developed by using digital storytelling such as personal development/interpersonal skills, media literacy skills, technical skills, and study skills. Besides, it is suitable for growing the students' interest in learning. The students' English language skills also can be increased by using digital storytelling. On the contrary, as said by Christiansen and Koelzer (2016), "A teacher's lack of understanding of the essential components of digital stories can 
lead to the ineffective implementation of DST activities in the EFL classroom."

According to Morgan (2014), commonly in producing digital storytelling follow these steps: Firstly, the students write a story. The stories are based on their experiences such as when they were traveling to a place, going to the zoo, etc. They can write it on a paper. Second, the students draw and give number to the scenes in order to match with the narration on a storyboard. After that, the students collect some graphics to complete the scenes such as photographs and clip art. In this section, the students can search and collect all relevant images, photographs, and clip art from their photos album on android or download it on google.com.

Next, the students can import the recording narration and combine the files into a movie form with a video-editing program such as Movie Maker or iMovie. In other words, they record their stories which they have already written and import into video editing program. The students can use Movie Maker or iMovie; however, to make it easier, the students can use their own smartphone or android as a video-editing tool. The last step, the students can add a title to complete their own editing of digital storytelling. When the students are ready, they can export the digital story-completed in order to play with using Window Media Player file or others. The students also can share the produced-digital stories to online media such as YouTube, Facebook, Line, etc.

Obviously, there are some benefits and disadvantages of digital storytelling (DST). However, the most previous studies have already found that digital storytelling can provide a meaningful activity in the process of teaching and learning. It can help the students improve their confidence in English language such as writing and speaking skills. Besides, digital story can help the students communicate their own stories effectively and provide the students-centered activity in teaching and learning. Furthermore, digital storytelling can help the students to acquire varieties of skill, especially 21 st century skills. Therefore, the writer has curiosity to investigate this matter related to the application of digital storytelling in the classroom as a medium in teaching speaking.
In other words, this study aims to explore the application of digital storytelling in teaching speaking, the benefits of digital storytelling in contributing to speaking skill, and the participants' perceptions related to the application of digital storytelling in teaching speaking.

\section{METHOD}

This study adopted a qualitative study. In selecting participants, the researcher used purposive sampling. The participants used in this study were one English teacher and six students of $11^{\text {th }}$ Social 1, the state senior high school No 1 Pelepat, Kab. Bungo. The participants were selected because of these certain specific characteristics; first, one English teacher who she ever applied and used digital storytelling minimal three times in the class. Second, the students (both males and females) who they ever had experience in learning English with digital storytelling.

To collect the data, the writer used observation, interview, and audiovisual material. This study was qualitative which the data were analyzed qualitatively by using the stages of data analysis proposed by McKernan as cited in Burns (1999 p. 157) they are assembling data, coding data, comparing data, building interpretations, and reporting the outcomes. To check the data validity in this study, the researcher used triangulation.

\section{RESULTS AND DISCUSSION}

First, digital storytelling use in learning provided the students to have motivation (not boredom) and improved their English speaking. Second, students' lack of efficient technology skills might cause students to have difficulty and problems in the digital storytelling process. Third, the use of digital storytelling helped and activated students to have motivation in English speaking skill. They could practice repeatedly and evaluate their English speaking skill by themselves, especially pronunciation. Fourth, digital storytelling could improve the students ${ }^{\text {ee }}$ confidence to speak English. Fifth, the benefits of digital storytelling in contributing to students ${ }^{\text {ee }}$ 
speaking skill were students can understand and practice English language, especially speaking skill. They were familiar with the pronunciations of English. Besides, it also provided them to practice English speaking skill with their classmates in the class because they were brave to speak English each other.

The researcher summarized the findings from interviews related to the aplication of digital storytelling in teaching speaking into three themes; they are procedures, benefits, and perceptions. For the process, there were some procedures of digital storytelling if it will be used in teaching speaking. In short, the processes were started from writing the story, recording the voice, collecting the images, combining/editing the voice and the images, and presenting the produced digital storytelling. Related to benefits, the application of digital storytelling could contribute to improve students' speaking skill because it provided the students to be familiar with the pronunciations of English language and they could practice it many times. Besides, the students had confidence to make communications with their friends in the classroom. In addition, the use of digital storytelling in teaching speaking had contribution in evaluating or assessing the students $^{\text {ee }}$ speaking skill with ease, especially in the process of recording and presentation. Related to perceptions, the researcher wrote down the perceptions from the English teacher and students. According to the English teacher, digital storytelling was a powerful and entertaining, and pleasant media which it could be used in the teaching and learning to provide a student to be creative, high motivation, and out of boredom. Besides, digital storytelling was helpful media in teaching. According to the students, digital storytelling use in learning provided them to have motivation (not boredom), too. But, some of the students had problems related to limited time and lack of relevant images.

\section{The Application of Digital Storytelling in Teaching Speaking}

The first research question of this study was how does the application of digital storytelling in teaching speaking? Through this study, the writer found out that the English teacher applied digital storytelling in teaching speaking with following these procedures: firstly is writing. In this step, the students begin with writing the story. The story can be written whether based on personal experience, histories of life, or narrative story. In this activity, the students also seemed enthusiasm to write their own story because they can express their own idea and tell their experience to share to other people. By asking the students to tell and share their own personal story or what they have experienced, they become more motivated in English teaching and learning process.

\section{The Benefits of Digital Storytelling in Contributing to Speaking}

Second research question of this study was what benefits can digital storytelling contribute to speaking skill? Through this study, the application of digital storytelling could contribute to improve students' speaking skill because it provided the students to be familiar with the pronunciations of English language and they could practice it many times. Furthermore, the students had confidence to make communications with their friends in the classroom. In other words, digital storytelling could contribute to speaking class such as the students had motivation in learning which they enjoyed the speaking activity, not boredom, the students were creative and they could understand the story with pictures. In addition, the use of digital storytelling in teaching speaking had contribution in evaluating or assessing the studentse speaking skill with ease, especially in the process of recording and presentation. Besides, the use of digital storytelling could help the teacher in teaching. 
The Participants' Perception related to the Application of Digital Storytelling in Teaching Speaking

According to the English teacher, digital storytelling was a powerful, an entertaining, and a pleasant media which it could be used in teaching and learning to provide a student to be creative, high motivation, and out of boredom. Besides, digital storytelling was helpful media in teaching.

According to the students, the application of digital storytelling in teaching speaking provided them to have motivation (not boredom) which they liked in learning speaking because they could see and understand on the visualization pictures in the form of video in digital storytelling. However, not all students had positive perception on digital storytelling use in teaching speaking, but there were some of the students had negative perceptions. Some of the students had problems in creating digital storytelling such as difficult in editing, limited time, and lack of relevant images. It happened to students because they had the lack of technology skill. Therefore, related to the application of digital storytelling in teaching speaking, it can be understood that digital storytelling can provide students to have positive and negative perceptions.

\section{CONCLUSION}

There are three main conclusions of this present study. First, digital storytelling is applied in teaching speaking as in the following procedures: writing the story, recording the story with a good pronunciation and intonation, collecting the pictures that related to the story, combining both the story-recorded and relevant images, and the last step is the presenting and evaluating the produced-digital storytelling.

Second, the application of digital storytelling has some benefits such as it contributes to students to practice and improve their speaking skill. The students are familiar with the pronunciations of
English language. They are self-confidence in communications with their friends in the classroom. They can evaluate or assess their improvement in speaking skill especially in the step of recording and presentation.

Lastly, the use of digital storytelling in teaching speaking provides participants to have positive and negative perception; for example, it allows students to have motivation in learning. It is easy, interesting, and enjoyable media, while for negative perceptions relate to difficulties in editing, limited time, and lack of related images.

\section{REFERENCES}

Boase, C. 2016. Digital Storytelling for Reflection and Engagement: a study of the uses and potential of digital storytelling. Retrieved $26^{\text {th }}, 2016$, from https://gjamissen. files.wordpress.com /2013/05/boase_assessment.pdf

Burns, Anne. 1999. Collaborative Action Research for English Language Teachers. Cambridge: Cambridge University Press.

Christiansen, M. S., and Koelzer, M. L. 2016. Digital Storytelling: Using Different Technologies for EFL. MEXTESOL JOURNAL, Vol. 40, No. 1, 2016 Retrieved August 29 , 2016, from http://mextesol.net/journal/index.php?p age $=$ journal\&id_article $=1338$

Franscy and Fatimah, Rezki P.S.N. (2019). An Analysis of Factors Influencing Learners' in Learning Language. DLEJ (Dialectical Literature and Education Journal). 4(1). 1-9. Retrieved from https://dlejpancasakti.ac.id/index.php/dlej pancasakti/issue/view/1

Ketabdar, Z., et. al. 2014. The Relationship between Emotional Intelligence and Willingness to Communicate among Iranian EFL Learners vol.3 (3) retrieved July $28^{\text {th }}$, 2016, from www.european-science.com

Kim, S. 2014. Developing Autonomous Learning for Oral Proficiency Using Digital Storytelling. Language Learning \& Technology 18(2), retrieved 
$26^{\text {th }}, \quad 2016$, from http://llt.msu.edu/ issues/ june2014/action1.pdf

Morgan, H. 2014. Digital Storytelling Project Help Improve Reading and Writing. Canada: retrieved June $12^{\text {th }}$, 2016 from https://www.literacyworld wide.org/blog/literacy-daily/2014/04/16 /digital-storytelling-projects-helpimprove-reading-and- writing-

Petrucco, C. 2014. Digital Storytelling as a Reflective Practice Tool in a Community of Professional: Best Research Paper Award Winner. Annual Conference, 2014 Zagreb. Italy: University of Padua
Sepp, M., and Bandi-Rao, S. 2015. Creating an Effective Model for Digital Storytelling in the Writing Class. NYS TESOL JOURNAL Vol. 2, No. 1, January 2015

Tahriri, A., et. al. 2015. The Impact of Digital Storytelling on EFL Learnerse Oracy Skill and Motivation. International Journal of Applied Linguistics \& English Literature: Vol.4. 3; May 2015

Widodo, H. P. 2014. Engaging young learners of English in a genre-based digital storytelling project: Cambridge University Press 